\title{
Implementation One-Data Initiative and Network Relations between Actors in Maritime and Fisheries Field
}

\author{
Afini Mahabas ${ }^{1}$ \\ Ministry of National Development Planning/Bappenas - Indonesia
}

\begin{abstract}
This study aims to determine the inter-actor relationships at the Ministry of Marine Affairs of Fisheries (KKP) and outside the KKP in implementing the One Marine and Fishery Data system. The goal, of achieving unified standardized data are unified standardized metadata and a single data portal and the role of actor in solving data issues that existed in the previous KKP. The approach adopted is to use a networking model to find out more about networking principles such as collective action, degree of sharing and interdependency. The research result states that network relations among the activity factors of the One Marine Fishery Data are driven more by the regulations that applied before. Although this is counterproductive to the spirit of network, interactor network relationships can be realized based on the characteristics of the network. It is also supported by strong leadership at the KKP. There is the need to improve coordination in communication, particularly with parties outside the KKP, strengthen strategies by network managers, and reframe perceptions of actors related to the objectives of the One Marine and Fishery Data, so that networking relationships in these activities will grow.
\end{abstract}

Keywords: network (networking), one data, collective action, interdependence

${ }^{1}$ Afni Mahabas is a staff at Center for Data and Information Pusat, Ministry of National Development Planning/ Bappenas, Indonesia. Email: afini.mahabas@bappenas.go.id 


\section{Implementasi Inisiatif Satu Data dan}

Hubungan Jejaring Antar Aktor di Bidang Kelautan dan Perikanan

Afini Mahabas

\section{Latar Belakang}

Menyusun suatu kebijakan berdasarkan data yang akurat sangat penting guna menyelesaikan suatu masalah lebih tepat sasaran. Menurut Keban (2014:58) di dalam perumusan kebijakan ada tiga tipe kesalahan, kesalahan-kesalahan tersebut cen derung karena adanya kesalahan dalam memanfaatkan data dan informasi baik secara sengaja ataupun tidak disengaja oleh para administrator publik. Selain itu, administrator publik juga perlu melakukan koordinasi pada saat perencanaan, implementasi maupun kontrol terhadap keputusan suatu kebijakan publik (Chandler \& Plano).

Secara fenomena teoritis, pendekatan kerjasama di dalam suatu organisasi perlu memperhatikan hubungan atau interaksi dengan lingkungan agar dapat mencapai keseimbangan yang dinamis dan bersifat partisipatif. Dijelaskan oleh Goldsmith dan Eggers (2004:8) bahwa birokrasi hierarkis sudah tidak lagi dapat memenuhi permintaan yang kompleks dan dianggap tidak cocok untuk menghadapi permasalahan masyarakat yang sering melampaui batas-batas organisasi. Toole (2004) dan McGuire (2006) menyampaikan bahwa ada dua fenomena terkait kolaborasi antarpemerintah yaitu pentingnya pergeseran pendekatan organisasi kerjasama antardaerah dari konsep intra organization ke arah interorganization, selain itu kerjasama antardaerah yang hubungan strukturnya bersifat "relasi horisontal" dengan semangat kolaborasi akan lebih memiliki kekuatan dalam melakukan collective action. Sehingga pengembangan dalam melakukan pengelolaan masalah publik melalui kerjasama ataupun kolaborasi dengan melakukan pengembangan terhadap jejaring (network) menjadi sangat relevan, terutama untuk mengelola hubungan antar lapis pemerintah yang berbasis tanpa paksaan, hubungan yang sederajat, serta adanya kesadaran bersama antaraktor karena memiliki keterkaitan dan ketergantungan untuk mencapai tujuan yang sama (intergovernmental network) (Pratikno, dkk 2007).

Kualitas data yang buruk, kurangnya koordinasi, kelangkaan technical skills, buruknya legal framework serta adanya political barriers menyebabkaan keterbukaan data (open data) menjadi terhambat dan menyulitkan terjadinya perubahan yang berkelanjutan (World Wide Web Foundation, 2014), keadaan tersebut juga terjadi 
di Indonesia.Untuk mengatasi masalah-masalah di atas, perlunya solusi untuk menjawab semua kesulitan yang ada dengan melakukan reformasi tata kelola data. Salah satunya dengan mengeluarkan kebijakan keterbukaan data (open data) dalam bentuk Satu Data Indonesia (SDI) yang perlu dilaksanakan dengan mengedepankan prinsip-prinsip network dalam kegiataan pengelolaan data secara bersama. Kementerian Kelautan Perikanan (KKP)ditunjuk sebagai institusi pilot dalam mengimplementasikan inisiasi tersebut dansaat ini telah meluncurkan program Satu Data di lingkungan KKP. Program tersebut bertujuan agar seluruh jajaran KKP baik di pusat maupun daerah dapat mendukung terciptanya data yang berintegritas untuk mencapai Satu Data Kelautan Perikanan (Satu Data KP).

Berdasarkan latar belakang dan permasalahan di atas, maka rumusan masalah dalam penelitian ini adalah bagaimana hubungan jejaring (networking) antaraktor di lingkungan internal KKP dan dengan pihak eksternal KKP, dalam pelaksanaan Satu Data Kelautan Perikanan? Selain itu penelitian ini juga mempertajamnya dengan melihat mekanisme pengaturan terhadap peran aktor yang terlibat dalam kegiatan Satu Data Kelautan Perikanan, serta faktor-faktor apa saja yang mempengaruhi hubungan jejaring tersebut.

\section{Tinjauan Pustaka}

\subsection{Model Inter Organization dan Model Intraorganization}

Model pemerintahan saat ini sudah tidak lagi didominasi oleh komponen pemerintah saja, Lay dan Mashudi (2005, dalam Aisah dan Tauran, 2014) menyampaikan bahwa governance dibentuk oleh sektor publik (public sector), sektor privat atau swasta (private sector), dan masyarakat (civil society).Pergeseran pandangan dari government ke governance turut mempengaruhi adanya sikap kesejajaran atau kesamaan derajat yang akan berpengaruh terhadap tata kelola pemerintahan. Penting untuk dipahami oleh komponen pemerintah agar dapat melakukan kerjasama dengan pihak lain diluar pemerintah (non-pemerintah), supaya segala permasalahan dapat diselesaikan dengan lebih inovatif serta terciptanya proses demokratisasi dengan memberikan jaminan hak-hak politik kepada masyarakat dan tidak lagi bersifat hierarkis.Secara garis besar, kata kunci dari governance adalah consensus building dan akomodasi kepentingan sebagai basis dalam membangun sinergi (Pratikno, 2008).

Goldsmith dan Eggers (2004:8 dalam Aisah dan Tauran, 2014) menyampaikan bahwa birokrasi hierarkis sudah tidak lagi dapat memenuhi permintaan yang 


\section{Afini Mahabas}

kompleks dan dianggap tidak cocok untuk menghadapi permasalahan masyarakat yang bermunculan justru ada kemungkinan akan menimbulkan permasalahanpermasalahan baru (Scharpf,1978; Hanf dan Scharpf,1978; dalam Pratikno,2008). Dalam hal ini Kickert, dkk (1999; dalam Pratikno, 2008) menggambarkan model organisasi rasional (intra-organization) dengan model organisasi kerja sama (interorganization) ke dalam tabel berikut:

Tabel 1. Pendekatan Model Intra Organization dan Model Interorganization

\begin{tabular}{|c|c|c|}
\hline Model & \multirow[t]{2}{*}{ Intra Organisasi / Intra Organization (Rasional) } & \multirow{2}{*}{$\begin{array}{l}\text { Inter-Organisasi / } \\
\text { Interorganization }\end{array}$} \\
\hline Dimensi & & \\
\hline Proses & $\begin{array}{l}\text { Rasional, diatur dari atas, berorientasi } \\
\text { tujuan, instrumentatif } \\
\text { Perencanaan, pengorganisasian, dan } \\
\text { pengontrolan }\end{array}$ & $\begin{array}{ll}\text { - } & \text { Pertukaran } \\
& \text { sumberdaya dan } \\
\text { interaksi inter- } \\
\text { organisasional; } \\
\text { Berdasarkan kontrak } \\
\text { organisasional antar } \\
\text { lembaga }\end{array}$ \\
\hline Keputusan & $\begin{array}{l}\text { - Hasil perumusan strategis dari otoritas } \\
\text { pusat } \\
\text { - Ditujukan untuk mencapai tujuan yang } \\
\text { telah dirumuskan }\end{array}$ & $\begin{array}{ll}\text { - } & \text { Hasil dari negosiasi } \\
\text { antar organisasi } \\
\text { - } & \text { Ditujukan untuk } \\
\text { melestarikan alur } \\
\text { sumberdaya dan } \\
\text { menjaga interaksi }\end{array}$ \\
\hline $\begin{array}{l}\text { Kekuasaan } \\
\& \\
\text { Koordinasi }\end{array}$ & $\begin{array}{l}\text { - Jelas, ada struktur otoritas yang hierarkis } \\
\text { dan terpusat } \\
\text { - Kontrol menjadi mekanisme koordinasi }\end{array}$ & $\begin{array}{ll}\text { - } & \text { Tidak ada struktur } \\
\text { otoritas } \\
\text { - } \\
\text { dubungan kekuasaan } \\
\text { ditentukan oleh } \\
\text { keperluan atau } \\
\text { pertukaran } \\
\text { sumberdaya }\end{array}$ \\
\hline $\begin{array}{l}\text { Informasi } \\
\& \\
\text { Nilai }\end{array}$ & $\begin{array}{l}\text { - } \quad \text { Mencari informasi secara ilmiah } \\
\text { - } \quad \text { Ada tujuan dan nilai yang jelas }\end{array}$ & $\begin{array}{ll}\text { - Informasi adalah } \\
\text { sumber kekuasaan } \\
\text { yang dimiliki aktor } \\
\text { yang secara beragam } \\
\text { Nilai-nilainya sering } \\
\text { bertentangan }\end{array}$ \\
\hline
\end{tabular}

Sumber:Diolah Pratikno dari Kickert, Klijn, dan Koppenjan (1999:20) 
Berdasarkan hal tersebut, perlu dibangun suatu model governance yang baru sebagai alternatif dalam melakukan hubungan antarlapis pemerintah berupa pengembangan model jaringan (network). Scharpf (1978, dalam Klijn, 1999: 30) network diartikan sebagai hubungan langsung maupun tidak langsung yang didefinisikan oleh hubungan yang saling ketergantungan atau interdepedency. Selain ituakan melalui network akan tercipta proses saling memahami, saling berbagi informasi, mengidentifikasikan permasalahan secara bersama-sama (sharing) serta merencanakan aksi (collective action) untuk menyelesaikan permasalahan dengan bersama pula (Pratikno dkk, 2007 dalam Pratikno, 2004).

Pratikno (2007: 60) menyampaikan bahwa terdapat beberapa faktor yang dapat mempengaruhi terciptanya network seperti faktor komunikasi yang efektif, adanya kelembagaan yang jelas, faktor kesadaran sendiri dari masing-masing aktor dan tentu juga faktor kuatnya komitmen pemimpin. Selain memperhatikan faktor-faktor pengaruh, penting pula mendefinisikan peran-peran aktor serta memperhatikan mekanisme kerja dari aktor-aktor yang melakukan hubungan kerjasama tersebut. Hal ini bertujuan agar dalam implementasinya segala informasi yang dibutuhkan di dalam suatu jaringan dapat tersampaikan dan terkomunikasikan. Menurut Ostorm (1990, dalam Kickert dan Koppenjan 1999: 54), jumlah aktor yang terlibat hal tersebut tidak terlalu berpengaruh, namun hal yang harus diperhatikan bahwa aktor yang terlibat hanyalah orang-orang yang sangat diperlukan dengan memperhatikan kemampuan dan kapasitasnya.

\section{Metodologi}

\subsection{Proses Pengumpulan Data}

Dalam penelitian ini metode kualitatif digunakan untuk mendapatkan data primer dan data sekunder. Beberapa teknikdilakukan dalam proses penelitian ini seperti melakukan observasi, wawancara dan memanfaatkan beberapa dokumentasi yang adasebagai data sekunder. Dokumentasi yang dimaksud berupa catatancatatan, laporan, notulensi rapat, produk hukum, buku dan media tertulis lainnya baik yang tersedia di dalam suatu publikasi cetak maupun elektronik. Observasi atau pengamatan dilakukan terhadap aktivitas dan ketersediaan sumber daya yang ada di lingkungan KKP dan BPS, serta keterlibatan aktor di dalamnya. Wawancara dilakukan kepada narasumber di KKP dan BPSmulai dari pimpinan hingga staf pelaksana kegaitan. Hasil wawancara ini digunakan sebagai data primer 
dalam penelitian. Dalam teknis pelaksanaannya, wawancara dilakukan dengan menggunakan metode terstruktur dan tidak terstrukturnamun tetap mengacu kepada pedoman wawancara yang telah dibuat sebelumnya. Selain itu, wawancara ini juga dilakukansebagai tahapan untuk melakukan klarifikasi terhadap data yang didapatkan dari hasil observasi ataupun yang didapatkan dari teknik lainnya.

Berikut beberapa kebutuhan akan data primer dan sekunder yang digali lebih lanjut untuk dapat menjawab pertanyaan dari penelitian yang telah ditentukan:

Tabel 2. Daftar Kebutuhan Data

\begin{tabular}{|c|l|}
\hline No & \multicolumn{1}{|c|}{ Data Primer } \\
\hline 1 & Tata aturan relasi (networking) \\
\hline 2 & Tujuan para aktor berjejaring \\
\hline 3 & Ketersediaan sumberdaya \\
\hline 4 & Mekanisme keterlibatan aktor \\
\hline 5 & Komitmen pimpinan \\
\hline 6 & Konflik yang muncul \\
\hline 7 & Pola komunikasi \\
\hline No & \multicolumn{1}{|c|}{ Data Sekunder } \\
\hline 1 & $\begin{array}{l}\text { Peraturan-peraturan yang berkaitan dengan inisiasi Satu Data Indonesia dan } \\
\text { Cetak Biru Satu Data Indonesia, Instruksi Menteri KKP tentang Pelaksanaan } \\
\text { SI di internal KKP, dan aturan-aturan lainnya yang terkait. }\end{array}$ \\
\hline 2 & $\begin{array}{l}\text { Catatan dan data laporan pendukung yang ada seperti catatan rapat } \\
\text { (notulensi) koordinasi antaraktor terkait inisiasi Satu Data Indonesia dan } \\
\text { Satu Data Kelautan Perikanan }\end{array}$ \\
\hline 3 & $\begin{array}{l}\text { Profil unit terkait, mekanisme koordinasi antara unit satu dengan unit } \\
\text { lainnya baik di lingkungan internal ataupun eksternal }\end{array}$ \\
\hline 4 & $\begin{array}{l}\text { Data-data statistik sebagai produk yang dihasilkan dari kolaborasi yang } \\
\text { dilakukan oleh para aktor }\end{array}$ \\
\hline
\end{tabular}

\subsection{Analisis Data}

Proses analisis data secara keseluruhan melibatkan usaha memaknai data yang berupa teks atau gambar. Creswell (2009) dan Rossman \& Rallis (1998, dalam Creswell) menyatakan analisis data merupakan proses berkelanjutan yang membutuhkan refleksi terus-menerus terhadap data, mengajukan pertanyaan-pertanyaan analitis dan menulis catatan singkat sepanjang penelitian. Secara sederhana, proses analisis data 


\section{Afini Mahabas}

kualitatif dapat berupa proses pengumpulan data, interpretasi dan pelaporan hasil.

Dalam penelitian ini proses analisis data terdiri dari pengumpulan, pengolahan dan persiapan data yang akan dianalisis. Dalam tahap ini data primer hasil wawancara dilakukan transkripsi kemudian disederhanakan, dipilah yang sesuai untuk menjawab pertanyaan penelitian. Tahapan selanjutnya yaitu penyajian kembali data yang sudah diolah ke dalam narasi sebagai langkah untuk menyampaikan hasil analisis. Penerapan pendekatan naratif antara lain terdiri dari pembahasan kronologi peristiwa ataupun kegiatan Satu Data Kelautan Perikanan, yang telah dilaksanakan. Interpretasi atau memaknai data dilakukan pada tahap selanjutnya dengan menyampaikan kesimpulan hasil analisis, seperti memaknai data tata alur relasi, mekanisme peran aktor, ketersediaan kekuatan yang dimiliki oleh para aktor serta bagaimana komitmen seorang pemimpin yang dibandingkan dengan instrumen regulasi, finansial dan komunikasi yang juga dikaitkan dengan management strategie. Selanjutnya hasil dari pemaknaan tersebut akan dituangkan ke dalam suatu kesimpulan hasil analisis.

Untuk menjaga adanya keabsahan data, dalam prosesnya dilakukan teknik triangulsi data. Dalam pelaksanaannya triangulasi data dilakukan pada saat melakukan wawancara, guna mendapatkan kebenaran lebih lanjut dari data-data yang telah diperoleh.

\section{Hasil Penelitian}

Dari analisis yang telah dilakukan terhadap pola relasi antaraktor dalam kerjasama jejaring (networking) kegiatan Satu Data Kelautan Perikanan serta peran aktor dan mekanisme kerja yang tercipta, dengan turut pula memperhatikan karakteristik network yakni collective action, derajat sharing yang tercipta, dan hubungan saling ketergantungan antaraktor (interdepedency), dapat dijabarkan hasil yang disajikan berikut dengan mengelompokan penjabarannya menjadi tiga bagian sesuai dengan pertanyaan penelitian.

\subsection{Relasi Antaraktor Dalam Program Satu Data Kelautan Perikanan}

Model relasi network kegiatan Satu Data Kelautan Perikanan dapat terlihat di dalam tabel berikut yang mana mempertimbangkan beberapa karakteristik yang digunakan seperti adanya tindakan bersama (collective action), derajat sharing, dan hubungan saling ketergantungan diantara aktor yang terlibat (interdepedency): 
Tabel 3. Relasi Antaraktor dari Berbagai Dimensi

\begin{tabular}{|c|c|c|}
\hline Dimensi & Karakteristik & Pola Relasi \\
\hline \multirow{2}{*}{ Pelaku/Aktor } & $\begin{array}{c}\text { Keterlibatan Para } \\
\text { Aktor }\end{array}$ & $\begin{array}{l}\text { Aktor yang terlibat di dalam jaringan Satu Data Kelautan Perikanan terdiri dari pihak } \\
\text { internal KKP yang telah dibentuk dan diatur melalui Keputusan Menteri KKP yang disebut } \\
\text { Tim Satu Data Kelautan Perikanan. Selain itu terdapat pihak eksternal KKP, yakni BPS } \\
\text { sebagai pembina data statistik nasional }\end{array}$ \\
\hline & $\begin{array}{c}\text { Inisiatif Aktor } \\
\text { yang Berjejaring }\end{array}$ & $\begin{array}{l}\text { Karaktersitik networking seperti adanya kesadaran sendiri dan tanpa adanya paksaan, masih } \\
\text { belum sepenuhnya dipahami oleh seluruh aktor yang berjejaring. Keadaan yang terjadi } \\
\text { justru aktor-aktor tersebut berpartisipasi karena adanya dorongan berupa regulasi dari } \\
\text { pimpinan dan dorongan/ajakan dari aktor kunci/utama }\end{array}$ \\
\hline $\begin{array}{c}\text { Kekuasaan \& } \\
\text { Koordinasi }\end{array}$ & $\begin{array}{l}\text { Instrumen } \\
\text { Regulasi di dalam } \\
\text { Network }\end{array}$ & $\begin{array}{l}\text { Kerangka regulasi menjadi salah satu instrumen kuat pendorong terciptanya kerjasama } \\
\text { antaraktor kegiatan Satu Data Kelautan Perikanan. Mulai dari adanya Instruksi Menter } \\
\text { tentang moratorium sistem informasi yang terpusat (yang berdampak dengan adanya } \\
\text { kebijakan terpusatnya anggaran pengelolaan data di Pusdatin), regulasi yang membentuk } \\
\text { dan mengatur Tim Satu Data Kelautan Perikanan yang tertuang dalam Kepmen KKP, hingga } \\
\text { dorongan dari Sekjen KKP ke Pemerintah Daerah (untuk Gubernur/Bupati/Walikota) } \\
\text { berupa surat permohonan dukungan pelaksanaan kebijakan Satu Data Kelautan Perikanan }\end{array}$ \\
\hline \multirow{3}{*}{ Proses } & $\begin{array}{l}\text { Network } \\
\text { Governance } \\
\text { dalam Proses } \\
\text { Pengembangan } \\
\text { Jaringan }\end{array}$ & $\begin{array}{l}\text { Terciptanya kesepakatan bersama untuk mencapai tujuan jaringan (public purpose), } \\
\text { mengembangkan jaringan serta menjalankan policy. Terbukti dengan adanya produk } \\
\text { bersama berupa Pedoman Listing Pelaku Usaha di Wilayah Kab/Kota yang digunakan } \\
\text { oleh seluruh aktor sebagai pedoman dalam menjalani kegiatan survei di lapangan untuk } \\
\text { menghasilkan data pelaku usaha by name by address }\end{array}$ \\
\hline & Collective Action & $\begin{array}{l}\text { Telah terbentuk } 9 \text { (sembilan) Inisiatif Satu Data KKP yang masing-masing dikelola bersama } \\
\text { Tim Satu Data Kelautan Perikanan. Serta terciptanya pengelolaan sumberdaya secara } \\
\text { bersama }\end{array}$ \\
\hline & $\begin{array}{l}\text { Sharing of } \\
\text { Resources }\end{array}$ & $\begin{array}{l}\text { Masing-masing aktor yang terlibat di dalam jaringan, saling berkontribusi dengan berbag } \\
\text { (sharing) sumberdaya yang mereka miliki dan disesuakan dengan kemampuan ataupun } \\
\text { kompetensinya masing-masing, sehingga kepentingan individu dapat direduksi dan } \\
\text { dijadikan sebagai kepentingan bersama untuk mencapai tujuan satu data }\end{array}$ \\
\hline \multirow{4}{*}{$\begin{array}{c}\text { Informasi \& } \\
\quad \text { Nilai }\end{array}$} & $\begin{array}{l}\text { Sharing of } \\
\text { information }\end{array}$ & $\begin{array}{l}\text { - Terdapat forum diskusi yang dimanfaatkan untuk berkoordinasi diantara aktor-aktor yang } \\
\text { terlibat, tanpa ada kewenangan yang mendominasi. } \\
\text { - Terciptanya komunikasi yang cair dan tidak berjenjang di lingkungan internal KKP (Tim } \\
\text { Satu Data Kelautan Perikanan) terutama dalam membahas hal teknis, salah satunya dengan } \\
\text { memanfaatkan teknologi komunikasi } \\
\text { - Komunikasi dengan pihak eksternal KKP masih dirasa kurang optimal. Komunikasi masih } \\
\text { bersifat satu arah dan kurang terbuka, sehingga menyebabkan adanya perbedaan informasi } \\
\text { yang didapatkan oleh aktor-aktor di dalam jaringan }\end{array}$ \\
\hline & Sharing of benefits & $\begin{array}{l}\text { Pengelolaan data kelautan perikanan yang dilakukan bersama menghasilkan adanya } \\
\text { kemudahan dalam mengolah \& mengumpulkan data dan dapat dimanfaatkan oleh berbaga } \\
\text { pihak. Dengan kolaborasi, data-data tersebut terkumpul di dalam satu sistem (Aplikasi Satu } \\
\text { Data) yang mudah diakses, sehingga kebutuhan pimpinan untuk pengambilan kebijakan } \\
\text { dapat dilakukan dengan cepat (efisien) dan lengkap (s.d level kabupaten), terciptanya } \\
\text { transparansi terutama dalam memberikan bantuan untuk nelayan }\end{array}$ \\
\hline & $\begin{array}{l}\text { Sharing of } \\
\text { experience }\end{array}$ & $\begin{array}{l}\text { Aktor yang pernah memiliki pengalaman dalam melakukan pengumpulan data di lapangan } \\
\text { berbagi dengan aktor lain, salah satunya dapat dijadikan alternatif solusi terhadap suatu } \\
\text { masalah yang sama }\end{array}$ \\
\hline & $\begin{array}{l}\text { Interdepedency } \\
\text { antaraktor }\end{array}$ & $\begin{array}{l}\text { Munculnya sikap saling ketergantungan yang tinggi diantara aktor-aktor yang terlibat di } \\
\text { dalam network Satu Data Kelautan Perikanan (engagement relatif tinggi) karena masing- } \\
\text { masing aktor saling bertujar sumberdaya (exchange) dan memiliki kepentingan untuk } \\
\text { memperoleh manfaat }\end{array}$ \\
\hline
\end{tabular}

Sumber:Peneliti (diolah) dengan menyesuaikan konsep dari Kickert, Klijn dan Koppenjan (1999:20) 


\subsection{Peran Aktor dan Mekanisme Kerja}

Di dalam hubungan kerjasama jejaring Satu Data Kelautan Perikanan, telah terdefinisikan dengan jelas pembagian peran dan tugas dari aktor internal KKP melalui Keputusan Menteri Kepmen-KP No.201/Kepmen-KP/SJ/2017. Untuk melihat kesesuaian berdasarkan kemampuan dan tanggung jawabnya masing-masing, maka peran-peran tersebut dipetakan dengan menggunakan konsep Goldsmith \& Eggers (2004) yang mempertimbangkan faktor responsibilitas dan kemampuan aktor dalam menjalani perannya. Pemetaan peran tersebut dapat terlihat dalam tabel berikut:

Tabel 4. Peta Peran Aktor Jejaring Satu Data Kelautan Perikanan

\begin{tabular}{|c|c|c|c|}
\hline \multicolumn{2}{|r|}{ Goldsmith \& Eggers } & \multicolumn{2}{|c|}{ Kepmen No.201/Kepmen-KP/SJ/2017 } \\
\hline Peran Aktor & $\begin{array}{l}\text { Responsibilitas dalam } \\
\text { Organisasi Jaringan }\end{array}$ & Peran Aktor & Tugas Sesuai Keputusan Menteri \\
\hline $\begin{array}{l}\text { Chief } \\
\text { executive } \\
\text { officer; elected } \\
\text { official; } \\
\text { cabinet officer }\end{array}$ & $\begin{array}{l}\text { - } \quad \text { Memaksimalkan public } \\
\text { value } \\
\text { Mengidentifikasi nilai- } \\
\text { nilai dan talenta dari } \\
\text { pemerintah utama } \\
\text { Mengkomunikasikan visi } \\
\text { secara internal maupun } \\
\text { eksternal }\end{array}$ & Pengarah & $\begin{array}{l}\text { Memberikan arahan pelaksanaan } \\
\text { satu data di lingkungan KKP }\end{array}$ \\
\hline $\begin{array}{l}\text { Chief } \\
\text { operating } \\
\text { officer; } \\
\text { director }\end{array}$ & $\begin{array}{l}\text { - Membangun dan } \\
\text { memamage hubungan } \\
\text { dan strategi } \\
\text { Memahami kebutuhan } \\
\text { aktor penghubung (chief } \\
\text { relationship officer) }\end{array}$ & $\begin{array}{l}\text { Pelaksana } \\
\text { terdiri dari : } \\
\text { Tim Proses } \\
\text { Data, Tim } \\
\text { TI, dan Tim } \\
\text { SDM }\end{array}$ & $\begin{array}{l}\text { Menyusun arsitektur data, } \\
\text { blue print TI, menyusun } \\
\text { kebutuhan SDM pengolah } \\
\text { data, menyusun alur } \\
\text { komunikasi } \\
\text { Implementasi kegiatan } \\
\text { masing-masing bersama } \\
\text { anggota tim } \\
\text { Melakukan pengelolaan } \\
\text { terhadap kegiatan yang } \\
\text { dilakukan } \\
\text { Melakukan penguatan } \\
\text { akan kelembagaan data } \\
\text { (koordinasi, identifikasi } \\
\text { tugas fungsi tim) }\end{array}$ \\
\hline Manager & $\begin{array}{l}\text { - } \quad \text { Manage teams } \\
\text { Manage project and } \\
\text { outcomes (network } \\
\text { manager) }\end{array}$ & $\begin{array}{l}\text { Penanggung } \\
\text { Jawab }\end{array}$ & $\begin{array}{l}\text { Bertanggung jawab atas } \\
\text { pelaksanaan satu data di } \\
\text { lingkungan KKP }\end{array}$ \\
\hline Line worker & $\begin{array}{l}\text { Menyelesaikan permasalahan } \\
\text { para aktor dalam jaringan }\end{array}$ & - & - \\
\hline $\begin{array}{l}\text { Procurement } \\
\text { officer }\end{array}$ & $\begin{array}{ll}\text { - } & \text { Melakukan negosiasi } \\
\text { - } & \text { Meminta masukan ide } \\
\text { jaringan }\end{array}$ & - & \\
\hline $\begin{array}{l}\text { Chief } \\
\text { information } \\
\text { officer }\end{array}$ & $\begin{array}{l}\text { Mengatur kegiatan diseminasi/ } \\
\text { berbagi pengetahuan dan } \\
\text { informasi }\end{array}$ & $\begin{array}{l}\text { Penanggung } \\
\text { Jawab }\end{array}$ & $\begin{array}{l}\text { Bertanggung jawab atas } \\
\text { pelaksanaan satu data di } \\
\text { lingkungan KKP }\end{array}$ \\
\hline
\end{tabular}


Terkait peran line worker dan procurement officer, meskipun tidak terdefinisi di dalam Keputusan Menteri KKP, namun dalam pelaksanaan kegiatan Satu Data Kelautan Perikanan peran-peran tersebut secara berurutan dilakukan oleh UKM KKP selaku unit yang dibentuk langsung oleh Menteri KKP sebagai perpanjangan tangan Menteri KKP dan Pusdatin selaku aktor yang memiliki sumberdaya besar dalam kegiatan ini sejak adanya pemusatan anggaran pengelolaan data dan informasi kelautan perikanan. Kedua aktor ini dapat dikatakan merupakan aktor kunci atau aktor kuat dalam terciptanya hubungan jejaring kegiatan Satu Data Kelautan Perikanan.

Hal lain yang juga tidak kalah penting untuk diperhatikan adalah mekanisme koordinasi dan kolaborasi antaraktor dalam berinteraksi di jaringan, yang mana dapat digunakan sebagai langkah ataupun solusi dalam berkomunikasi dan menyelesaikan masalah yang muncul dan perlu dihadapi. Mekanisme tersebut tertuang di dalam Prosedur Operasi Standar Proses Pengumpulan Data Produksi Kelautan Perikanan. Prosedur tersebut telah disepakati oleh seluruh aktor yang terlibat sehingga dalam pelaksanaan kegiatannya dapat teratur dan terarah untuk dapat menghasilkan target yang ingin dicapai bersama yaitu tersedianya data produksi perikanan tangkap, perikanan budidaya, produk olahan dan garam yang valid dan berkualitas.

Setiap tahapan kegiatannya melibatkan berbagai peran yang ada di dalam tim dan juga melibatkan aktor-aktor yang ada di dalam jaringan, mulai dari pihak-pihak yang ada di Unit Eselon I KKP, Pusdatin, dan juga petugas pengambil data di lapangan atau enumerator. Masing-masing aktor tersebut telah ditentukan tugas-tugas yang harus mereka lakukan hingga tahap akhir. Setiap kegiatan-kegiatannya memiliki saling keterikatan, satu kegiatan dengan kegiatan lainnya tidak dapat terpisahkan ataupun dilewati untuk mencegah data produksi kelautan perikanan yang belum terverifikasi dan tervalidasi ketika nanti dipublikasikan. Berdasarkan kategori pembagian mekanisme kerja Hall dan O'Toole (jr) (2000), mekanisme kerja tersebut dikategorikan sebagai mekanisme kerja sequential, yang mencirikan adanya sikap saling ketergantungan (interdepedency) di antara aktor jaringan dalam menghasilkan target terciptanya satu data.

\subsection{Faktor Pengaruh Dalam Network Satu Data Kelautan Perikanan}

Terdapat berbagai faktor yang mempengaruhi network relation baik dari sisi pola kerjasama maupun peran aktor dalam kegiatan Satu Data Kelautan Perikanan. Adapun faktor-faktor penunjang (enabling) ataupun penghambat (constraining) sehingga tercipta hubungan tersebut, dapat dijelaskan di bawah ini. 
Faktor-Faktor Penunjang (enabling) Terciptanya Networking adalah sebagai berikut:

1. Komitmen pemimpin :

Adanya kerangka regulasi berupa Instruksi Menteri KKP No.389/2016 yang merupakan salah satu instrumen kuat sebagai dasar terimplementasikannya kegiatan Satu Data di lingkungan KKP, dapat terwujud karena adanya komitmen dari pimpinan KKP yang tinggi untuk segera merealisasikan terciptanya data yang satu di bidang kelautan dan perikanan. Realisasi lain dari instruksi tersebut yaitu melakukan pemusatan anggaran terhadap kegiatan pengelolaan data KKP di tahun 2017, yang kemudian diserahkan dan dikelola sepenuhnya oleh Pusdatin guna merealisasikan kegiatan satu data, dampaknya kegiatan pengelolaan data dan informasi di KKP menjadi lebih terkoordinasi dan terintegrasi.

2. Komunikasi yang Efektif :

Secara keseluruhan komunikasi antaraktor di dalam jaringan Satu Data Kelautan Perikanan dapat dikatakan berjalan dengan baik dan telah tercipta komunikasi yang tidak dibatasi oleh jenjang birokrasi yang hierarki dan kaku.

3. Kesadaran Aktor dalam Berbagi Sumberdaya :

Pada awal inisiasi ini dicanangkan, masih munculnya penolakan dari unit-unit di lingkungan KKP. Namun, dengan berjalannya waktu koordinasi diantaranya semakin menjadi lebih baik dan terciptanya kesadaran dari masing-masing individu untuk mengintegrasikan kegiatan pengelolaan data serta bersedia untuk berbagi sumber daya yang mereka miliki. Dengan adanya kesadaran untuk berbagi sumberdaya, maka muncul sikap saling ketergantungan (interdepedency).

4. Adanya Pembagian Peran Aktor dan Aktor Kunci Penggerak Network:

Dengan telah terbentuknya Tim Satu Data Kelautan Perikanan, mengindikasikan ada pelembagaan yang jelas mengatur siapa berwenang apa (pembagian peran dan tugasnya) hingga respon apa yang dapat diberikan apabila adanya ketidak samaan kekuasaan dan sumberdaya di dalam network (Pratikno, 2007:60). Hal tersebut ikut mempengaruhi intergovernmental network di dalam lingkungan KKP, masing-masing aktor akan berkontribusi dengan optimal karena sudah ada pembagian peran dan tugas yang jelas dan juga telah disesuaikan dengan kemampuan serta sumberdaya yang mereka masing-masing miliki. Selain itu hadirnya aktor kunci di dalam networking ikut memberikan 
kontribusi lebih dalam menjalankan relasi.

Faktor-Faktor Penghambat dalam Networking adalah sebagai berikut:

1. Faktor Waktu Implementasi yang Terlalu Singkat:

Banyaknya keluhan yang disampaikan oleh aktor (selain Pusdatin ataupun UKM KKP) terkait waktu perencanaan/ perancangan dan pelaksanaan kegiatan Satu Data Kelautan Perikanan yang dirasakan sangat singkat, menjadi salah satu faktor kendala di dalam kegiatan Satu Data Kelautan Perikanan. Ada beberapa hal yang dianggap terlalu dipaksakan karena kegiatan Satu Data Kelautan Perikanan di KKP harus segera diimplementasikan. Contohnya, untuk menggunakan metodologi survei yang baru sebenarnya dibutuhkan waktu yang memadai untuk melakukan penyesuaian dari metodologi survei yang lama, sehingga ada persiapan (masa transisi) agar tidak ada kegiatan (sebelumnya) tiba-tiba terhenti dan menciptakan inefisiensi anggaran.

2. Komunikasi yang Bersifat Satu Arah:

Seperti yang telah dipaparkan sebelumnya, komunikasi di dalam jaringan Satu Data Kelautan Perikanan dapat dikatakan telah berjalan dengan efektif. Namun, ada hal penting lainnya yang harus diperhatikan oleh manager network Satu Data Kelautan Perikanan terkait komunikasi antarpihak di luar lingkungan KKP. Seperti komunikasi yang terjadi antara KKP dengan BPS yang dirasakan masih bersifat satu arah. Dalam hal ini BPS selaku pembina data nasional dirasa tidak banyak diikut sertakan di dalam kegiatan Satu Data Kelautan Perikanan, terutama pada saat kegiatan redesign kuisoner dan metodologi survei serta dalam kegiatan monitoring di lapangan.

3. Perbedaan Ketertarikan Aktor terhadap Kegiatan:

Sikap ketertarikan (interest) masing-masing aktor terhadap kegiatan Satu Data Kelautan Perikanan berbeda-beda. Terlihat bagaimana aktor-aktor tersebut masih harus dipandu untuk terlibat di dalam jaringan tersebut, alasannya antara lain karena menganggap Pusdatin sebagai koordinator kegiatan yang memiliki banyak wewenang dalam menyusun jadwal koordinasi dan kegiatan lainnya. Selain itu, terdapat pendapat lain dari pihak yang berada di luar lingkungan KKP yang menyatakan kebingungan terhadap posisinya di dalam jaringan Satu Data Kelautan Perikanan, sehingga mereka cenderung pasif menunggu ajakan ataupun undangan dari pihak KKP saja. 


\section{Penutup}

\subsection{Kesimpulan}

1. Hubungan relasi didorong karena adanya kerangka regulasi yang menjadi instrumen kuat untuk mengikat dan memaksa aktor-aktor tersebut dalam membangun hubungan kerjasama pada kegiatan Satu Data Kelautan Perikanan. Hubungan yang bersifat hierarkis dan kaku masih ada, namun dengan adanya kerangka regulasi tersebut aktor-aktor di KKP justru mau bergerak dan sepakat untuk mencapai tujuan akhir.

2. Prinsip networking dalam bentuk tindak bersama (collective action) pada kegiatan Satu Data Kelautan Perikanan terwujud dalam 9 (sembilan) Inisiatif Satu Data KKP. Dalam setiap kegiatan koordinasi, diskusi di dalam forum yang mengarah konsensus dapat terwujud. Namun inisiatif dari masing-masing aktor yang berjejaring masih kurang dirasakan, misalnya setiap koordinasi mereka cenderung menunggu undangan ataupun ajakan dari aktor kunci/manager network.

3. Sikap saling berbagi (sharing) diantara aktor-aktor yang berjejaring telah diwujudkan dalam bentuk sharing of resources, benefit, dan experience yang dapat dikatakan berjalan dengan baik. Namun sharing of information belum terjalin dengan baik antara pihak KKP dengan pihak eksternal KKP seperti BPS dimana masih adanya komunikasi yang bersifat satu arah.

4. Sikap saling melengkapi dan menutupi kekurangan masing-masing aktor terutama dalam penyediaan \& pertukaran (exchange) sumberdaya disimpulkan bahwa hubungan saling ketergantungan terjadi di dalam jaringan.

5. Peran dari masing-masing aktor dalam hubungan kerjasama networking Satu Data Kelautan Perikanan telah terdefinisi dengan jelas dan diatur di dalam kebijakan internal KKP, dengan membentuk Tim Satu Data Kelautan Perikanan.

6. Terdapat aktor kuat di dalam jaringan Satu Data Kelautan Perikanan yakni UKM KKP dan Pusdatin selaku network manager, mereka lebih memiliki power, sumberdaya yang besar (berupa anggaran) serta kontribusi dalam menggerakan kegiatan kerjasama dan jaringan.

7. Mekanisme alur kerja pada proses pengumpulan data untuk menciptakan data yang satu di bidang kelautan perikanan bersifat sequential artinya ada sikap saling ketergantungan antaraktor dalam menjalankan kegiatan.

8. Faktor penunjang yang memiliki korelasi cukup tinggi dalam membentuk 
jaringan Satu Data Kelautan Perikanan yaitu adanya komitmen dari pimpinan di lingkungan Kementerian Kelautan Perikanan

9. Faktor penghambat yang cukup berpengaruh dalam hubungan jejaring antaraktor pada kegiatan kegiatan Satu Data Kelautan Perikanan yaitu faktor interest (ketertarikan) dari masing-masing aktor yang berbeda-beda sejak tahapan perencanaan hingga implementasi kegiatan.

\subsection{Saran}

1. Optimalisasi kerangka regulasi di dalam hubungan kerjasama jaringan:

Agar instrumen regulasi yang kuat tidak selalu menciptakan hubungan kerjasama yang terlalu bersifat kaku, instrumen regulasi dapat dioptimalkan pada saat implementasi kegiatan Satu Data Kelautan Perikanan dengan lebih mengedepankannya sebagai alat negosiasi dan konsensus diantara aktoraktor yang berjejaring, misalnya dimanfaatkan dalam mengelola tingkah laku (mengelola peran aktor) masing-masing aktor network sehingga dapat meningkatkan kinerja organisasi.

2. Mengubah persepsi para aktor dari nilai awal yang mereka pahami (reframing), serta lebih mengeksplorasi persamaan dan perbedaan persepsi menyelaraskan tujuan (covenanting):

Beberapa langkah covenanting sudah dilakukan di dalam jaringan Satu Data Kelautan Perikanan, namun langkah ini dapat dikombinasikan dengan strategi reframing untuk lebih memperbaiki perbedaan akan ketertarikan (interest) para aktor terhadap kegiatan Satu Data Kelautan Perikanan, yang juga akan ikut mempengaruhi inisiatif aktor-aktor tersebut dalam menggerakan dan mengembangkan jaringan.

3. Penguatan strategi steering untuk aktor kunci:

UKM KKP dan Pusdatin selaku aktor kunci dan manager jaringan, perlu memperhatikan setiap tindakannya agar tidak terlalu mendominasi di dalam jaringan melainkan menguatkan strategi dalam memanfaatkan kekuatan (steer) yang dimiliki dalam mengelola sumberdaya (resources) yang ada di masingmasing aktor untuk mencapai tujuan terciptanya satu data.

4. Membenahi komunikasi antara KKP dengan pihak eksternal, untuk menciptakan interdepedency:

KKP melalui Pusdatin perlu meningkatkan koordinasi mulai dari kegiatan 
perencanaan hingga kegiatan monitoring evaluasi khususnya dengan pihak eksternal KKP, agar dapat terciptanya komunikasi dan akan mereduksi missing communication dari masing-masing aktor. Dengan adanya koordinasi maka akan tercipta sharing informasi yang tinggi dan akan menciptakan adanya collective action (tindak bersama) dalam mengelola sumberdaya yang dimiliki oleh masing-masing aktor. Selanjutnya akan tercipta pula saling keterkaitan (interdepedency) di antara aktor-aktor yang bekerjasama, terutama untuk saling melengkapi kekurangan dan kelebihan yang dimiliki.

\section{Referensi}

Aisah, Siti Yuni \& Tauran. 2014. Kajian Governance Network dalam Program The Sunan Giri Awards di Kabupaten Gresik. Sagafnews Vol 1, September 2014.

Anonim. 2014. Cetak Biru Satu Data untuk Pembangunan Berkelanjutan. Jakarta: UKP4.

Bachri, Bachtiar S. 2010. Meyakinkan Validitas Data Melalui Triangulasi Pada Penelitian Kualitatif. Jurnal Teknologi Pendidikan, Vol. 10 No. 1, April 2010. Hal 46-62.

Carlson, Rals. 1996. Policy Networks as Collective Action. Diakses melalui laman: http://dlc.dlib.indiana.edu/dlc/bitstream/handle/10535/4366

Creswell, John W. 2009. Research Design Qualitative, Quantitative, and Mixed Methods Approaches Third Edition. California: SAGE Publication. Terjemahan oleh Achmad Fawaid. Yogyakarta: Pustaka Pelajar.

Davies, Tim.2014. Open Data in Developing Countries (ODDC) Summary of Emerging Insight from Phase I.Diakses melalui laman: http://www.opendataresearch.org/emergingimpacts

Dwiyanto, Agus. 2004. Reorientasi Ilmu Administrasi Publik: Dari Government ke Governance. Pidato Pengukuhan Jabatan Guru Besar. Fakultas Ilmu Sosial dan Ilmu Politik, Universitas Gadjah Mada: Yogyakarta.

Goldsmith, Stephen dan William D. Eggers. 2004 . Governing by Network The New Shape of The Public Sector. The Brookings Institution: Washington.

Innah, Henry Silka dkk. 2012. Peran Dinamika Jejaring-Aktor Dalam Reforestasi di Papua. Jurnal Penelitian Sosial dan Ekonomi Kehutanan, Vol. 9, No. 2, Juni 2012, Hal. 96-112.

Instruksi Menteri Kelautan Perikanan No. 389 Tahun 2016 Tentang Pelaksanaan Sistem Informasi di Lingkungan Kementerian Kelautan dan Perikanan.

Keban, Yeremias, T. 2014. Enam Dimensi Strategi Administrasi Publik Konsep, Teori dan Isu Edisi Ketiga. Yogyakarta: Penerbit Gava Media.

Keputusan Menteri Kelautan dan Perikanan Republik Indonesia Nomor Kep-26/ MEN/2008 Tentang Unit Kliring Departemen Kelautan dan Perikanan.

Keputusan Menteri Kelautan dan Perikanan Republik Indonesia Nomor 201/Kepmen-KP/SJ/2017 Tentang Tim Satu Data di Lingkungan Kementerian Kelau- 
tan dan Perikanan.

Kickert, Walter J.M, E. H. Klijn dan Joop. F.M. Koppenjan. 1999. Managing Complex Networks: Strategies for The Public Sector. Sage Publication: London.

Meek, Jack W and Kurt Thurmaier. 2012. Network Governance The Future of Intergovernmental Network. CQ Press: United States of America.

Pasolong, Harbani. 2012. Metode Penelitian Administrasi Publik. Bandung: Alfabeta.

Peraturan Kepala BPS No. 7 Tahun 2000 tentang Tata Cara Penyelenggaraan Survei Statistik Sektoral

Peraturan Menteri Kelautan dan Perikanan Republik Indonesia Nomor 33/Permen-KP/2015 Tentang Unit Kerja Menteri Kementerian Kelautan dan Perikanan.

Peraturan Menteri Kelautan dan Perikanan Republik Indonesia Nomor 6/Permen-KP/2017 Tentang Organisasi dan Tata Kerja Kementerian Kelautan dan Perikanan.

Pratikno dkk. 2004. Format Kelembagaan Kerjasama Antar Daerah Kertamantul. Urban-Quality GTZ dan Sekber Kertamantul: Yogyakarta.

Pratikno. 2007. Governance dan Krisis Teori Organisasi. Jurnal Kebijakan dan Administrasi Publik. Vol 11, Nomor 2, hal 121-138. Magister Administrasi Publik, Universitas Gadjah Mada: Yogyakarta. dkk. 2007. Kerjasama Antar Daerah: Kompleksitas dan Tawaran Format Kelembagaan. Yogyakarta: Program S2 Politik Lokal dan Otonomi Daerah UGM \& JIP Fisipol UGM 2008. Manajemen Jaringan dalam Perspektif Strukturisasi. Jurnal Kebijakan dan Administrasi Publik. Magister Administrasi Publik Universitas Gadjah Mada, Vol 12, No. 1, hal 1-19.

Purwanto, Erwan Agus dan Dyah Ratih Sulistyastuti. 2012. Implementasi Kebijakan Publik: Konsep dan Aplikasinya di Indonesia. Penerbit Gava Media: Yogyakarta.

Pusat Data Statistik dan Informasi-KKP. 2017. Pedoman Survei Listing Pelaku Usaha Kelautan Perikanan. Pusat Data Statistik dan Informasi.

Robbins, Stephen P. 1990. Teori Organisasi: Struktur, Desain \& Aplikasi Edisi 3. Alih bahasa Jusuf Udaya. Peneribit Arcan: Jakarta.

Sagala, Saut dkk. 2013. Interaksi Aktor dalam Rekonstruksi Rumah Pascabencana Gempa Bumi. Mimbar, Vol 29, No. 2 (Desember 2013), hal 217-226.

Thoha, Miftah. 2008. Ilmu Administrasi Publik Kontemporer. Jakarta: Kencana.

Undang-Undang No. 16 Tahun 1997 Tentang Statistik

Undang-Undang No. 4 Tahun 2011 Tentang Informasi Geospasial

Warsono, Hardi. 2009. Networking Dalam Intergovernmental Management. Dialogue JIAKP (Jurnal Ilmu Administrasi dan Kebijakan Publik) Vol. 6, No. 1 Januari, hal 78-91.

Yukl, Gary A. 1994. Kepemimpinan Dalam Organisasi. Edisi Bahasa Indonesia dari Leadership in Organization 3e. Prenhallindo: Jakarta. 